Zusammenfassung. Bis auf wenige Ausnahmeindikationen führen wir bei Oberarmschaftbrüchen die von Sarmiento angegebene funktionelle Behandlung mittels Kunststoffoberarmmanschette durch. Nach der Reposition wird zur Abschwellung eine Oberarmgipsschiene für 5-10 Tage angelegt. Anschließend wird die Sarmientomanschette angepaßt und mit funktionellen Bewegungsübungen begonnen. Von 31 konsekutiven Humerusschaftfrakturen wurden 26 funktionell mit der Sarmientomanschette behandelt. Es kam in allen Fällen zu einer knöchernen Konsolidierung in 6-8 (in einem Fall in 11) Wochen ohne sekundäre Komplikationen. In zwei Drittel der Fälle kam es zu geringen Achsabweichungen. Das funktionelle Ergebnis war jedoch durchwegs gut.

Schlïsselwörter: Oberarmschaftbrüche - funktionelle Behandlung - Sarmiento-Kunststoffmanschette.

\title{
258. Probleme der Indikationsstellung zur konservativen Frakturbehandlung am Beispiel der Oberarmschaftfraktur
}

\author{
S. Decker und J. Rehn
}

Unfallchirurgische Klinik Friederikenstift Hannover, D-3000 Hannover und Chirurgische Universitätsklinik „,Bergmannsheil“", Hunscheidstraße 1, D-4630 Bochum

\section{Problems Concerning the Indication for Conservative Treatment of Fractures, Using the Humerus Shaft Fracture as an Example}

Summary. An analysis of the causes of 142 humerus shaft pseudoarthroses and the examination of the results of 124 conservatively and 88 operatively treated humerus shaft fractures indicate that the conservative therapy of certain fracture types can be problematic. Consequently, an extension of the indication is recommended for operative therapy in the sense of a plate osteosynthesis along the lines of the AO.

Key words: Humerus shaft fracture - Operative - Conservative - Indication.

Zusammenfassung. Eine Analyse der Ursachen von 142 Oberarmschaftspseudarthrosen und die Überprüfung der Resultate von 124 konservativ sowie 88 operativ behandelten Oberarmschaftfrakturen zeigen, da $\beta$ die konservative Therapie bei bestimmten Frakturformen problematisch ist. Es wird daher eine Erweiterung der Indikationsstellung zur operativen Therapie im Sinne der Plattenosteosynthese nach den Richtlinien der AO empfohlen.

Schliisselwörter: Oberarmschaftfrakturen - Konservativ - Operativ - Indikation.

\section{Fehler bei der Osteosynthese von Oberarmschaftfrakturen}

\author{
B. Gay, J. Riemenschneider und B. Gutzeit \\ Chirurgische Universitätsklinik Würzburg (Direktor: Prof. Dr. E. Kern), \\ Josef-Schneider-Straße 2, D-8700 Würzburg
}

\section{Errors in Reconstruction of the Humerus}

Summary. From 1973 to 1982,86 patients underwent corrective surgery after previous orthopedic procedures on the humerus. The unfavorable results were due to inadequate fixation (wire cerclage, fixation with screws, inadequate intramedullar fixation or rush pins) or technical errors (radial nerve lesions, inadequate exposure or fixation, improper intramedullar insertion). Corrective procedures should be performed as soon as possible.

Key words: Humerus - Corrective surgery.

Zusammenfassung. Von 1973 bis 1982 führten wir bei 86 Patienten Korrekturoperationen am Oberarm nach vorangegangener Osteosynthese durch. Die Mißerfolge waren entweder durch unzureichende Osteosyntheseverfahren (Drahtcerclage, Einzelverschraubung, dünne Marknägel oder Rush-pins) oder durch fehlerhafte technische Durchführung (Radialisschäden, ungenügender Zugang, insuffiziente Plattenosteosynthese, falsche Einschlagstelle der Bündelnägel) bedingt. Die Indikation zur Korrekturoperation sollte rechtzeitig erfolgen.

Schliisselwörter: Oberarmosteosynthese - Korrekturoperation. 